\title{
Response of Nitrogen Fertilizer Rate on Yield and Yield Components of Malt Barley (Hordeum vulgare L.) Varieties at Arsi Zone, Ethiopia
}

\author{
Fasil Shimels ${ }^{1}$, Demelash Kefale ${ }^{2}$ \\ ${ }^{1}$ Kulumsa Agricultural Research Center, Ethiopia Institute of Agricultural Research, Addis Ababa, Ethiopia \\ ${ }^{2}$ School of Plant and Horticulture Science, College of Agriculture, Hawassa University, Hawassa, Ethiopia
}

Email address:

fasrabit1982@gmail.com (F. Shimels)

\section{To cite this article:}

Fasil Shimels, Demelash Kefale. Response of Nitrogen Fertilizer Rate on Yield and Yield Components of Malt Barley (Hordeum vulgare L.) Varieties at Arsi Zone, Ethiopia. World Journal of Food Science and Technology. Vol. 5, No. 3, 2021, pp. 50-54. doi: $10.11648 /$ j.wjfst.20210503.13

Received: September 29, 2021; Accepted: October 26, 2021; Published: October 30, 2021

\begin{abstract}
Identifying optimum nitrogen fertilizer rate for barley production especially malt barley is an important agronomic parameter for increment of yield and yield components. Thus the experiment was conducted during 2018/19 cropping season with an objective of evaluating the response of nitrogen fertilizer rate on growth, yield and yield components of malt barley varieties at West Arsi, Ethiopia. A factorial combination of five nitrogen levels $(11.5,23,34.5,46$ and $57.5 \mathrm{~kg} \mathrm{~N}$ $\mathrm{ha}^{-1}$ ) and three malt barley varieties (Holker, Ibon and Fanaka) was laid down in a split plot arrangement nitrogen as main plot and varieties as subplot with in three replication. Malt barley yield and yield components were considered as experimental variable. Thus the result reveal that grain yield of malt barley was highly significant effect by interaction of nitrogen and varieties. While, days to heading, days to maturity, plant height, number of productive tillers, straw yield and number of grain per spike were significantly affected by both factors. Higher $\left(2.75 \mathrm{tha}^{-1}\right)$ grain yield was recorded from the combination of Ibon variety with $57.5 \mathrm{~kg} \mathrm{~N}^{-1}$. Therefore from this research study it can be conclude that, fertilization of $57.5 \mathrm{~kg} / \mathrm{ha} \mathrm{N}$ fertilizer rate for Ibon variety was found to be better in terms of both agronomic performance and economic feasibility for malt barley production in the study area and similar agro ecology.
\end{abstract}

Keywords: Growth Parameters, Malt Barley, Nitrogen, Varieties, Rate of Nitrogen

\section{Introduction}

Barley (Hordeum vulgare L.) is belonging to grass family poaceae and is cereal grain crop. After wheat, maize and rice barley ranks fourth in the world in terms of production Global barley production is estimated about 141.7 million tons [22]. In Africa next to Morocco, Ethiopia is the second largest barley producer $[10,19]$. Next to tef, maize, sorghum and wheat barley is the fifth important cereal crop [7].

In Ethiopia, Barley production started long years ago and is largely grown as a food crop. It is growing in the central and northern parts of Ethiopia, including; Oromia, Amhara, Tigray, and Southern part of Ethiopia, [2]. The use of malt barley as a row material in brewery factories has increased its value and the demand of farmers to produce [2].

Malt barley is largely a commercial crop produced for the market both for industrial malt grain production and for cottage local beer and liquor production [20]. Barley has been used as animal fodder, as a source fermentable material for beer and certain distilled beverages, and as a component of various health foods. It is used in soups and stews, and in barley bread of various cultures. Barley (Hordeum vulgare L.) is the most important staple food and subsistence crop in Ethiopia. Its grain is used for the preparation of different foodstuffs, such as injera, kolo, and local drinks, such as tela, borde and beer Very recently it is being adopted for preparation of bread all alone or mixed with wheat [12].

Know a day, Malt barley consumption in Ethiopia is increasing due to the establishment of malt factory, growth of population and a gradual change of lifestyle, but its productions have not expanded as required, and productivity is still low. It is due to several constraints like depletion of 
soil fertility, which is caused by intensive cropping, imbalanced fertilization, limited application of organic manures, and soil erosion [6].

The rate of $\mathrm{N}$ fertilizer application is among the most critical decisions for barley grain production and productivities because of its large impact on grain yield, and yield components of malt barley. Nitrogen fertilizer application may have to be restricted to rates that are less than those required for maximum yield in order to achieve acceptable protein content for malting barley.

Varieties also play an important role for increasing yield production and productivity of malt barley. Consequently assessing grain yield and yield components of malt barley varieties to different rate of $\mathrm{N}$ fertilizer is important since little or too match nitrogen fertilizer may decrease yield and yield components of malt barley (Grant et al. 1991a). The aim of this study was to investigate the effect of different nitrogen fertilizer rates on growth, yield and yield components of three malt barley varieties at Arsi Zone, Ethiopia.

\section{Materials and Methods}

A study to investigate response of nitrogen fertilizer rates on yield and yield components of malt barley varieties was conducted at Arsi zone of Ethiopia, during main cropping season 2018/19. The experimental site is located from $07^{\circ} 30^{\prime}$ $37^{\prime} \mathrm{N}-39^{\circ} 11^{\prime} 31^{\prime \prime} \mathrm{E}$ with altitude ranging $2751 \mathrm{~m}$.a.s.l. The mean annual rain fall of this site was $951.5 \mathrm{~mm}$ and 4.05 and $19.88^{\circ} \mathrm{C}$ of minimum and maximum temperature respectively. Randomized complete block design (RCBD) with split plot arrangement: fertilizer rate as main plot and varieties as sub plot was used in three replication. Five rates of $\mathrm{N}(11.5,23$, $34.5,46,57.5) \mathrm{kg} \mathrm{ha}^{-1}$ and three malt barley varieties (Ibon, Fanaka and Holker) were considerd as main plot and sub plot factors respectively. The total plot and the harvested plot areas were 10.4 and $7.8 \mathrm{~m}^{2}$ respectively. The land was ploughed using oxen and plots was level manually TSP was apply full does at sowing time and urea fertilizer was incorporated to the soil in split application. $1 / 2$ does during planting time and the remaining $2 / 3$ applied at the crop reach at mid tillering stage. Recommender rate $\left(125 \mathrm{~kg} \mathrm{ha}^{-1}\right)$ of malt barley seeding rate was used as planting material. Planting was done in row by manual row marker and other management practice was performed per research recommendations.

\subsection{Data Collection}

\subsubsection{Phonological Parameters}

Days to $50 \%$ physiological maturity: Days to $50 \%$ maturity was collected in individual plot base at a plant when $50 \%$ of the plant reaches fully mature.

Days to $90 \%$ physiological maturity: Data on $90 \%$ days to maturity was collected in plot base when $90 \%$ of the plant was fully mature. It recorded by visualizing.

\subsubsection{Growth Parameters}

Plant height $(\mathrm{cm})$ : plant height was recorded by measuring five randomly selected plant from the surface up to the tip of the spike own at harvesting time (physiological maturity) stage. It recorded in plot base.

\subsubsection{Yield and Yield Components}

Number of productive tillers per plant: It was counted by hand from five randomly selected plants from harvestable area in plot base.

Grain Yield t/ha: It was recorded from 9 central row in each plot and converted to tone per hectare after adjusting grain moisture contain with $12.5 \%$.

Straw yield tha: Straw yield was simply measured by subtracting of grain yield from biomass yield.

Harvest Index (HI\%): The harvest index was calculated by dividing biological yield to biomass yield and multiplied by 100. It expressed in percentage.

\subsection{Analyzing of Data}

Data analyzing was performed following the standard procedure of split plot arrangement using PROC GLM procedure of SAS software version 9.2 [16]. Mean separation was done following the significance of mean squares by using LSD at 55 levels of significance.

\section{Result and Discussion}

\subsection{Phenological Parameters}

\subsubsection{Days to 50\% Physiological Maturity}

The main effects of fertilizer rate and varieties were highly significant $(P \leq 0.01)$ effect on days to $50 \%$ physiological parameter, while the interaction was not significant. According to the data longest (66.8) and shortest (60.9) days to $50 \%$ physiological maturity was determined from fertilization of 57.5 and $11.5 \mathrm{~kg} \mathrm{~N} \mathrm{ha}^{-1}$ respectively. This showed that increasing nitrogen fertilizer from initial too high (57.5), result in consistently increases days to $50 \%$ physiological maturity. The result was supported by Mekonen [11] who reported that days to maturity was significantly affected when nitrogen fertilizer applied with highest rate for wheat and barley with comparative of lowest rate. In addition to this Rashied et al [15] elaborated that days to maturity of barley was significantly affected by nitrogen fertilizer rate.

Significant variation also was observed in days to maturity among the tasted varieties.

\subsubsection{Days to 90\% Physiological Maturity}

This parameter was significant effect among varieties and fertilizer rate, while the interaction was not significant. 46 and $57.5 \mathrm{~kg} \mathrm{ha}^{-1}$ nitrogen fertilizer rate were at pare and show significant difference among the remaining three rates. (112.1) and (99) days to maturity was recorded from application of (57.5 and 11.5) $\mathrm{kg} \mathrm{n} \mathrm{ha}^{-1}$ respectively (Table 1). This increase was likely to be associated with the inherent role of nitrogen fertilizer that increases vegetative growth of the crop 
consequently it delayed maturity time. Damene Darota [8] elaborated similar result with this study: who indicating that significant differences induced by nitrogen treatments in plant maturity of wheat. Similar result was reported by Woinshet Tariku, [24] claiming that higher rates of nitrogen prolonged days to physiological maturity of malt barley.

Table 1. Effects of nitrogen fertilizer rate on $50 \%$ and $90 \%$ physiological maturity.

\begin{tabular}{|c|c|c|}
\hline \multirow[b]{2}{*}{$\begin{array}{l}\text { Treatment N } \\
\mathrm{kg} / \mathrm{ha}\end{array}$} & \multicolumn{2}{|l|}{ Parameters } \\
\hline & $\begin{array}{l}\text { Days to } 50 \% \\
\text { physiological maturity }\end{array}$ & $\begin{array}{l}\text { Days to } 90 \% \\
\text { physiological maturity }\end{array}$ \\
\hline 11.5 & $60.9^{\mathrm{c}}$ & $99.0^{\mathrm{d}}$ \\
\hline 23 & $63.3^{\mathrm{bc}}$ & $101.4^{\text {cd }}$ \\
\hline 34.5 & $64.5^{\mathrm{ab}}$ & $104.2^{\mathrm{c}}$ \\
\hline 46 & $65.7^{\mathrm{ab}}$ & $108.2^{\mathrm{b}}$ \\
\hline 57.5 & $66.8^{\mathrm{a}}$ & $112.1^{\mathrm{a}}$ \\
\hline LSD $0.05 \%$ & 2.69 & 3.3 \\
\hline CV\% & 3.2 & 2.4 \\
\hline \multicolumn{3}{|l|}{ Varieties } \\
\hline Holker & $70.1^{\mathrm{a}}$ & $111.1^{\mathrm{a}}$ \\
\hline Ibon & $55.9^{\mathrm{c}}$ & $100.4^{c}$ \\
\hline Fanaka & $66.7^{\mathrm{b}}$ & $104.8^{b}$ \\
\hline LSD $0.05 \%$ & 4.06 & 2.8 \\
\hline CV\% & 3.18 & 2.03 \\
\hline
\end{tabular}

Mean value with in columned followed the same letters are not significant different. $\mathrm{LSD}=$ list significant deference, $\mathrm{CV}=$ Cofficience of variation and ns $=$ non-significant different.

\subsection{Growth Parameters}

\subsubsection{Plant Height (cm)}

Varieties and nitrogen fertilizer rate shows significant variation $(P \leq 0.01)$ for plant height, but the interaction was not significant. When the dose of fertilizer rate increased from 11.5 to maximum rate $57.5 \mathrm{~kg} \mathrm{ha}^{-1}$ plant height also simultanessely increased. Tallest (82.7) and shortest (71.6) $\mathrm{cm}$ plant height was recorded from fertilization of 57.5 and $11.5 \mathrm{~kg} \mathrm{n} \mathrm{ha}^{-1}$ respectively (Table 2). Such increment of plant height along with increasing of fertilizer rate might is directly related to the effects of nitrogen which promotes vegetative growth. Wakene et al and Minale et al [23, 13] reported similar result with this finding: Nitrogen fertilizer rate increased from 0 to $69 \mathrm{~kg} \mathrm{ha}^{-1}$, the plant height of bread wheat was increased from 82.6 to $94.2 \mathrm{~cm}$.

\subsubsection{Number of Tillers per Plant}

Nitrogen fertilizer rate had significant effect $(P \leq 0.05)$, while varieties and the interaction effect with fertilizer were not significant for number of tillers per plant. Highest (4) and lowest (2.7) number of tillers per plant was recorded from application of 57.5 and $23 \mathrm{~kg} \mathrm{n} \mathrm{ha-}{ }^{1}$ respectively (Table 2). It also significantly increased in response to increasing application rate of nitrogen, since nitrogen promotes carbohydrate utilization and rapid plant growth via increasing number of tillers per plant

\subsubsection{Spike Length (cm)}

The main effect of fertilizer, variety and interaction effect of two factors not show significant different for spike length. Longer spike length $(5.6 \mathrm{~cm})$ was recorded for Holker variety.
Whereas the shortest spike length (5.0) $\mathrm{cm}$ was recorded from Fanaka variety (Table 2). Whereas the longest spike length (5.7) was recorded from $57.5 \mathrm{~kg} \mathrm{~N} \mathrm{ha}^{-1}$ fertilizer application in the study area.

Table 2. Effects of nitrogen fertilizer rate on plant height, spike length and number of tillers per plant.

\begin{tabular}{llll}
\hline \multirow{2}{*}{ Treatment } & \multicolumn{2}{l}{ Parameters } & STR \\
\cline { 2 - 4 } & PH & & \\
\hline N kg ha $^{-1}$ & & $2.7^{\mathrm{b}}$ & 4.9 \\
11.5 & $71.60^{\mathrm{d}}$ & $3.1^{\mathrm{ab}}$ & 5.3 \\
23 & $76.05^{\mathrm{c}}$ & $3.6^{\mathrm{ab}}$ & 5.3 \\
34.5 & $78.07^{\mathrm{b}}$ & $3.6^{\mathrm{ab}}$ & 5.6 \\
46 & $79.10^{\mathrm{b}}$ & $4.0^{\mathrm{a}}$ & 5.7 \\
57.5 & $82.70^{\mathrm{a}}$ & 1.21 & $\mathrm{~ns}$ \\
LSD 0.05\% & 2.9 & 7.1 & 11.5 \\
CV\% & 5.09 & & \\
Varities & & $3.3^{\mathrm{a}}$ & 5.6 \\
Holker & $86.1^{\mathrm{a}}$ & $3.8^{\mathrm{a}}$ & 5.3 \\
Ibon & $73.5^{\mathrm{b}}$ & $3.1^{\mathrm{a}}$ & 5 \\
Fanaka & $72.9^{\mathrm{b}}$ & 1.5 & $\mathrm{~ns}$ \\
LSD 0.05\% & 2.7 & 12.1 & 7.8 \\
CV\% & 3.1 & & \\
\hline
\end{tabular}

Means in column followed by the same letter are not significant different at $5 \%$ level of significant, $\mathrm{SD}=$ Least significant difference, $\mathrm{CV}=$ Coefficient of variation, $\mathrm{PH}=$ plant height $(\mathrm{cm}), \mathrm{Sl}=$ spike length $(\mathrm{cm}), \mathrm{NTR}=$ Number of tillers per plant.

\subsection{Yield and Yield Components}

\subsubsection{Number of Productive Tillers per Plant}

Variety and fertilizer rate sow significant $(P \leq 0.05)$ difference for number of productive tillers per plant. Comparison of treatment means indicated that number of productive tillers generally increased with increasing nitrogen fertilizer rates. Hence, maximum number of productive tillers (34.7) was produced from $57.5 \mathrm{~kg} \mathrm{~N} \mathrm{ha}^{-1}$, whereas the lowest number of productive tillers (28.4) was obtained from plants grown with initial nitrogen fertilizer application (Table 3). The result was in agreement with Abdullatif et al. [1], who reported that, the number of productive tillers increased with nitrogen fertilization. Similarly, Evans et al., [9] found that tillering is enhanced by increased light and nitrogen availability during the vegetative crop phase. Prystupa et al., [14] reported that the number of productive tillers of barley was affected significantly by $\mathrm{N}$ fertilizer application.

Statistically significant variation was observed on number of productive tillers of the tested varieties in the study area. the highest (35.1) number of productive tillers was recorded from Ibon variety, unlike, Holker and Fanaka varieties which produced statistically similar and lower number of productive tillers (32.5 and 26.1) respectively.

\subsubsection{Number of Grains / Spike}

The analysis of variance of this study reveals that number of grains /spike was significant $(P \leq 0.01)$ for both fertilizer rate and varieties, while the interaction effect was not significant. The highest (25.7) and lowest (23.6) was measured from fertilization of 57.5 and $11.5 \mathrm{~kg} \mathrm{~N} \mathrm{ha}^{-1}$ 
respectively (Table 3 ). It showed a linear and positive response to nitrogen fertilizer rate in all rates. This might be the ability of the plants to uptake, translocation, assimilate and use nitrogen for the photosynthesis and development of spikelet. Shafi et al., [18] elaborate similar result with this result: He stated that nitrogen application at the rate of $60 \mathrm{~kg}$ $\mathrm{ha}^{-1}$ result in maximum number of grains per spike. Schulthess et al., Tilahun et al. [17, 21] who reported that application of nitrogen fertilizer from low to higher level there was grate variation to number of grains per spike.

\subsubsection{Straw Yield $\mathrm{tha}^{-1}$}

In both fertilizer rate and varieties straw yield show significant variation $(P \leq 0.05)$, but the interaction effect was not significant. (13.99 and 8.76) $\mathrm{t} \mathrm{ha}^{-1}$ were highest and lowest straw yield that obtained from fertilization of 57.5 and $11.5 \mathrm{~kg} \mathrm{~N}^{-1}$ respectively (Table 3 ). Increasing nitrogen rate from 11.5 to highest rate $57.5 \mathrm{~kg}$, linearly increase straw yield from 8.76 to $13.9 \mathrm{t} \mathrm{ha}^{-1}$, this implies that $52.3 \%$ higher than the initial fertilizer rate (Table 3 ). Increase in straw yield in response to fertilization of nitrogen rate might be due to the enhanced, uptake resulting in induction of vigorous vegetative growth with more leaf area leading to higher photosynthesis and more dry matter accumulation. The result of this study was in line with; Amsal et al., [5] who found that increased nitrogen fertilizer rate significantly enhanced the straw yield of wheat, since $\mathrm{N}$ usually promotes the vegetative growth of plants.

There were also significant differences $(P<0.05)$ among the three varieties of malt barley in straw yield. The highest (13.21 ton $\mathrm{ha}^{-1}$ ) mean straw yields was recorded from Ibon variety, whereas the lowest straw yields at both locations were recorded from Fanaka variety (Table 3).
Table 3. Effect of Nitrogen fertilizer rates on yield and yield components of malt barley.

\begin{tabular}{llll}
\hline \multirow{2}{*}{ Treatment } & \multicolumn{2}{l}{ Parametrs } & \\
\cline { 2 - 4 } & NPT & GPS & SY t ha $^{-1}$ \\
\hline N kg ha $^{-1}$ & & & \\
11.5 & $28.40^{\mathrm{c}}$ & $23.60^{\mathrm{b}}$ & $8.76^{\mathrm{b}}$ \\
23 & $29.40^{\mathrm{c}}$ & $23.70^{\mathrm{ab}}$ & $11.61^{\mathrm{ab}}$ \\
34.5 & $30.50^{\mathrm{bc}}$ & $24.80^{\mathrm{ab}}$ & $11.61^{\mathrm{ab}}$ \\
46 & $33.40^{\mathrm{ab}}$ & $25.20^{\mathrm{ab}}$ & $12.39^{\mathrm{ab}}$ \\
57.5 & $34.70^{\mathrm{a}}$ & $25.70^{\mathrm{a}}$ & $13.99^{\mathrm{a}}$ \\
LSD 0.05\% & 3.5 & 2.06 & 2561 \\
CV\% & 8.7 & 6.3 & 7.6 \\
Varities & & & \\
Holker & $32.50^{\mathrm{a}}$ & $25.60^{\mathrm{a}}$ & $10.97^{\mathrm{ab}}$ \\
Ibon & $35.10^{\mathrm{a}}$ & $24.30^{\mathrm{a}}$ & $13.21^{\mathrm{a}}$ \\
Fanaka & $26.10^{\mathrm{b}}$ & $23.80^{\mathrm{b}}$ & $9.26^{\mathrm{b}}$ \\
LSD 0.05\% & 4.3 & 1.6 & 2689 \\
CV\% & 8.2 & 6.8 & 2.08 \\
\hline
\end{tabular}

Means in column followed by the same letter are not significantly different at $5 \%$ level of significant; $\operatorname{LSD}(0.05 \%)=$ Least significant difference at $5 \%$ level; $\mathrm{CV}=$ Coefficient of variation. $\mathrm{NS}=$ non- significant different, NPT = Number of productive tillers per $50 \mathrm{~cm}^{2}$; GPS $=$ Grains per spike and SY t $\mathrm{ha}^{-1}=$ Straw yield ton $\mathrm{ha}^{-1}$.

\subsubsection{Grain Yield $\mathrm{tha}^{-1}$}

Grain yield was significant variation $(\mathrm{P}<0.001)$ was obtained from interaction of variety and nitrogen fertilizer rate. Highest (2.63) and lowest (1.39) t ha-1 grain yield was recorded from fertilization of 57.5 and $11.5 \mathrm{~kg}$ ha- 1 with Ibon and Fanaka varieties respectively (figure 1). This grain yield variation might be help for selection of better varieties for varied nitrogen available environment. This result was supported by [3] reported that dry matter accumulation of barley increased with nitrogen fertilizer rate. In agreement with the current result [4] who stated that malt barley grain yield was increased with nitrogen fertilizer rate increased.

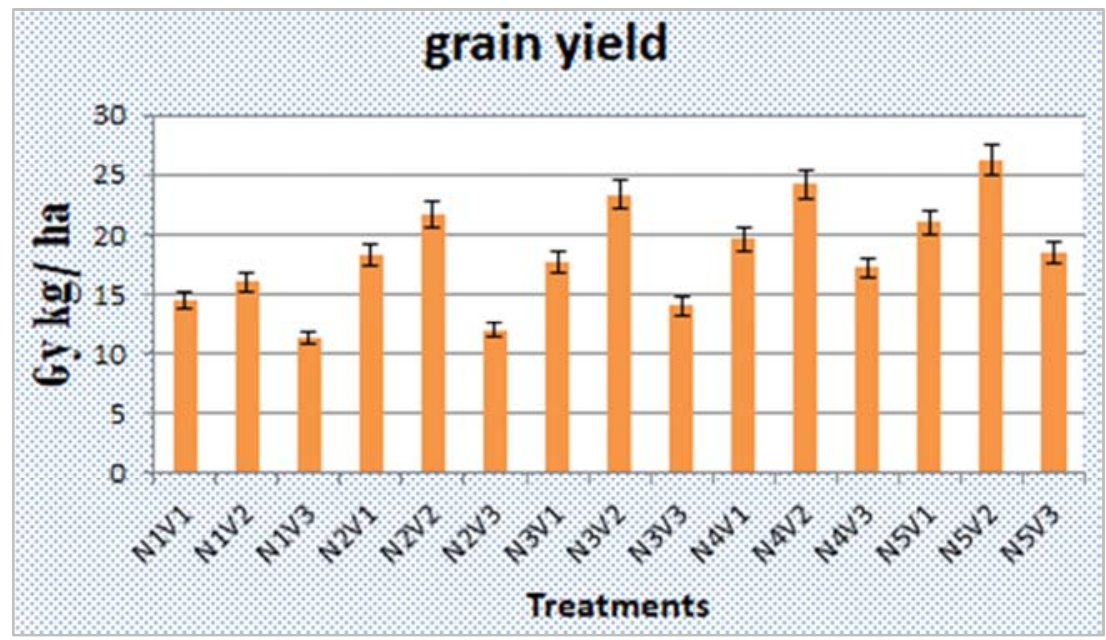

Figure 1. Interaction effect of Nitrogen fertilizer rate and malt barley varieties on grain yield.

\section{Conclusion}

A field experiment was conducted during 2018/19 main cropping season at Arsi Zone Ethiopia, with the objective of Response of Nitrogen fertilizer rate on yield and yield components of malt barley (Hordeum vulgare L.) varieties. Data on phonological growth, yield and yield components malt varieties were collected and analyzed. Number of tillers per plant, plant height, and number of grains per spike and straw yield of malt barley varieties increased with increasing $\mathrm{N}$ fertilizer rates. Yield of malt barley varieties also increased 
with increasing $\mathrm{N}$ fertilizers rates. However, the increased nitrogen rate which led to higher grain yield and grain protein didn't result beyond the acceptable range of malt quality. On the other hand application of higher $\left(57.5 \mathrm{~kg} \mathrm{ha}^{-1} \mathrm{~N}\right)$ fertilizer rates to Ibon variety generated better number of productive tillers, straw yield and grain yield with better economically benefit. Whereas the other two varieties Holker and Fanaka produced moderate amount of grain yield, but with lower economic benefit in the study area. Based on the present finding, the maximum grain yields $\left(2.60 \mathrm{t} \mathrm{ha}^{-1}\right)$ was recorded when the highest $\mathrm{N}$ fertilizer rate $\left(57.5 \mathrm{~kg} \mathrm{~N} \mathrm{ha}^{-1}\right)$ was applied for Ibon variety. Therefore Ibon malt variety with $57.5 \mathrm{~kg} \mathrm{~N} \mathrm{ha}^{-1}$ fertilizer could be recommended for the study area and similar agro-ecologies.

\section{References}

[1] Abdullatif M., Asmat U. M., Sattar A., Fiaz H., Abba G. and Huss J. 2010. Response of growth and yield of wheat to NPK fertilizer. Science international (Lahore), 24 (2): 185-189.

[2] Agricultural Transformation Agency (ATA). 2012. The business case for investing in a malting plant in Ethiopia.

[3] Alam M., Haider S. \& Paul N. 2005. Effects of sowing time and nitrogen fertilizer on barley (Hordeum vulgare L.). Bangladesh Journal of Botanical science, 34 (1): 27-30.

[4] Amare Aleminew \& Adane Legas. 2015. Grain quality and yield response of malt barley varieties to nitrogen fertilizer on Brown Soils of Amhara Region, Ethiopia. World Journal of Agricultural Sciences, 11 (3): 135-143.

[5] Amsal, T., Tanner, D., Taye, T. and Chanyalew, M. 2000. Agronomic and economic evaluation of the on farm $\mathrm{N}$ and $\mathrm{P}$ response of bread wheat grown on two contrasting soil types in Central Ethiopia. pp. 329. In: The 11th Regional wheat workshop for central, Eastern and Southern Africa. Addis Ababa, Ethiopia.

[6] Berhane Lakew, Chilot Yirga \& Wondimu F. 2016. Malt barley research and development in Ethiopia: opportunities and challenges. In: Dawit A., Eshetu D., Getnet A. Abebe K (eds). Proceedings of the National Conference on agricultural research for Ethiopian renaissance. Ethiopian Institute of Agricultural Research, Addis Ababa, Pp 11-20.

[7] CSA (Central statistical agency) agricultural sample survey. 2017. Report on area and production of major crops (private peasant holdings, Meher season). Volume I, Statistical bulletin. Addis Ababa, Ethiopia, Pp 10-12.

[8] Damene Darota. 2003. Yield Response of Bread Wheat (Triticum aestivum L.) to applied Levels of $\mathrm{N}$ and P Fertilizers on Nitisol of Dawro Zone, Southwestern Ethiopia, and M.Sc. thesis. Haramaya University, Haramaya.

[9] Evans L. T., Wardlaw L. F. and Fischer R. A. 1975. Wheat. In: Evans, L. T. (ed.). Crop Physiology Journal, Cambridge University Press, Cambridge.

[10] FAO (Food and Agriculture Organization). 2014. Food balance sheets. Faostat.

[11] Mekonnen Asrat. 2005. Response and uptake of barley (Hordeum irregulare L.) to different rates of OrgaP And nitrogen fertilizers on Nitisols of Gozamin District, Ethiopia. MSc Thesis, Haramaya University, Ethiopia.

[12] Melle Tilahun, Asfaw Azanaw and Getachew Tilahun. 2015. Participatory evaluation and promotion of improved food barley varieties in the highlands of north western Ethiopia. Wud pecker Journal of Agricultural Research, 4 (3): 050 - 053. https://www.researchgate.net/publication/332274412Nakano H., Satoshi Morita.

[13] Minale Liben, Alemayehu Assefa. \& Tilahun Tadesse. 2011. Grain yield and malting quality of barley in relation to nitrogen application at mid and high altitude in Northwest Ethiopia. Journal of Science and Development, 1 (1): 75-88.

[14] Prystupa P., Slafer G. \& Savin A. 2004. Leaf Appearance, Tillering and Their Coordination in Response to NxP Fertilization in Barley Springer, the Netherlands.

[15] Rashid A., Khan U. K. \& Khan, D. J. 2008. Comparative effect of varieties and fertilizer levels on barley (Hordeum vulgare L). Pakistan Journal of Soil Science, 1: 1-13.

[16] SAS. 2004. Software Syntax, Version 9.1, SAS Institute, Cary, NC, USA.

[17] Schulthess, U., B. Feil, and S. C. Jutzi. 1997. Yield independent variation in grain nitrogen and phosphorus concentration among Ethiopian wheats. Agron. J. 89 (3): 497-506.

[18] Shafi M., Bakht J., Jalal F., Khan A. \& Khattak G. 2011. Effect of nitrogen application on yield and yield components of barley (Hordeum Vulgare L.). Pakistan Journal of Botany, 43 (3): 1471-1475.

[19] Shahidur Rashid, Gashaw Abate, Solomon Lemma, James Warner, Leulsegged Kasa. \& Nicholas Minot. 2015. Barley value chain in Ethiopia: Research for Ethiopia s Agriculture Policy (REAP): Support for the Agricultural Transformation Agency (ATA).

[20] SIOF (Current Situation, Investment Opportunities and Future). 2013. Outlooks of malt barley Cultivars. International Journal of Biology Sciences, 3 (9): 298-303. https://repo.mel.cgiar.org/ handle/20.500.11766/4918.

[21] Tilahun Geleto, Tanner DG, Tekalign Mamo, Getinet Gebeyehu. 1996. Response of rain fed bread and durum wheat to source, level and timing of nitrogen fertilizer at two Vertisol sites in Ethiopia. pp. 127-147. In: The Ninth Regional Wheat Workshop for Eastern, Central and Southern Africa. Addis Ababa, Ethiopia.

[22] USDA (United States Department of Agriculture). 2017. Ethiopia Grain and Feed Annual Report. Global Agricultural Information Network (grain) Report ET-1503. Foreign Agricultural Service, USDA, Washington, DC. Retrieved MAY 17, 2018, from http://www.fas.usda.gov/data/ethiopia grain-and feed- annual.

[23] Wakene Tigre, Walelign Worku \& Wassie Haile. 2014. Effects of nitrogen and phosphorus fertilizer levels on growth and development of barley (Hordeum vulgare L.) at Bore district, Southern Oromia, Ethiopia. 2 (5): 260-266.

[24] Woinshet Tariku. 2007. Effect of nitrogen fertilizer levels on grain yield and malt quality of different malt barley (Hordeum vulgare L.) varieties in Shashemane Woreda. MSc. thesis, College of Agriculture, Hawassa. 